\title{
EFFECT OF FLUORIDATED VARNISH AND SILVER DIAMINE FLUORIDE SOLUTION ON ENAMEL DEMINERALIZATION: pH-CYCLING STUDY
}

\author{
EFEITO DO VERNIZ FLUORETADO E DA SOLUÇÃO DE DIAMINO FLUORETO DE \\ PRATA NA DESMINERALIZAÇÃO DO ESMALTE: ESTUDO UTILIZANDO \\ MODELO DE CICLAGEM DE PH
}

Alberto Carlos Botazzo DELBEM${ }^{1}$, Maurício BERGAMASCHI ${ }^{2}$, Kikue Takebayashi SASSAKI ${ }^{3}$, Robson Frederico CUNHA ${ }^{1}$

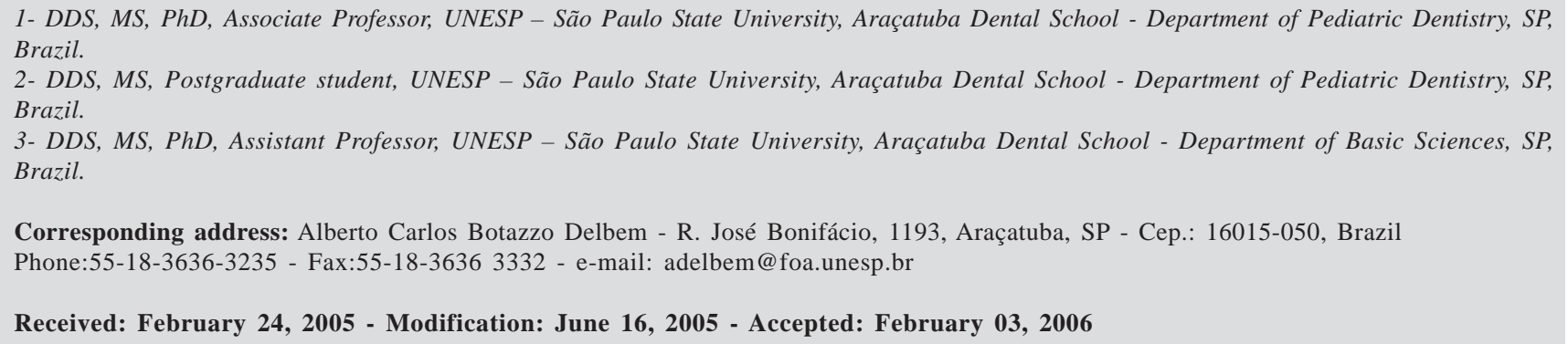

\begin{abstract}
$O$

bjective: In the present investigation, the anticariogenic effect of fluoride released by two products commonly applied in infants was evaluated. Methods: Bovine sound enamel blocks were randomly allocated to each one of the treatment groups: control (C), varnish (V) and diamine silver fluoride solution (D). The blocks were submitted to $\mathrm{pH}$ cycles in an oven at $37^{\circ} \mathrm{C}$. Next, surface and cross-sectional microhardness were assessed to calculate the percentage loss of surface microhardness $(\% \mathrm{SML})$ and the mineral loss $(\Delta \mathrm{Z})$. The fluoride present in enamel was also determined. Results: $\mathrm{F} / \mathrm{Px} 10^{-3}$ (ANOVA, $\left.\mathrm{p}<0.05\right)$ in the $1^{\text {st }}$ layer of enamel before $\mathrm{pH}$-cycling were (C, V and D): $1.61^{\mathrm{a}} ; 21.59^{\mathrm{b}}$ and $3.98^{\mathrm{c}}$. The \%SMH (Kruskal-Wallis, $\left.\mathrm{p}<0.05\right)$ were: $64.0^{\mathrm{a}},-45.2^{\mathrm{b}}$ and $-53.1^{\mathrm{c}}$. \% $\Delta \mathrm{Z}$ values (ANOVA, $\mathrm{p}<0.05$ ) were: $-18.7^{\mathrm{a}},-7.7^{\mathrm{b}}$ and $-17.3^{\mathrm{a}}$. Conclusion: The data suggested that the fluoride released by varnish showed greater interaction with sound enamel and provided less mineral loss when compared with silver diamine solution.

Uniterms: Enamel; Demineralization; Fluoride; Varnish; Dental caries, prevention and control.
\end{abstract}

\footnotetext{
RESUMO

bjetivos: Este trabalho avaliou o efeito anticariogênico do flúor liberado por dois produtos comumente aplicados em crianças. Métodos: Para isto, utilizaram-se blocos de esmalte de dentes bovinos distribuídos aleatoriamente em três grupos de tratamento: controle (C), verniz fluoretado (V) e solução de diamino fluoreto de prata (D). Os blocos foram submetidos à ciclagem de $\mathrm{pH}$ a $37^{\circ} \mathrm{C}$. Após, realizou-se o teste de microdureza de superfície (para o cálculo da \% da perda de microdureza de superfície - \%SML) e em secção longitudinal do esmalte (\% de alteração da área mineral - \% $\mathrm{Z}$ ) e a determinação do flúor presente no esmalte (F/P x 10 $0^{-3}$ ). Resultados: As concentrações de flúor (ANOVA, $\left.\mathrm{p}<0,05\right)$ na $1^{\text {a }}$ camada do esmalte, antes da ciclagem de $\mathrm{pH}$, foram (C, V e D): 1,6 $6^{\mathrm{a}}$; 21,6 $6^{\mathrm{b}}$ e 4,0 . Os resultados de \%SML (Kruskal-Wallis, $\mathrm{p}<0.05$ ) foram: $-64,0^{\mathrm{a}},-45,2^{\mathrm{b}}$ e $-53,1^{\mathrm{c}}$. Os valores de $\% \Delta Z$ (ANOVA, $p<0.05$ ) foram: $-18,7^{\mathrm{a}},-7,7^{\mathrm{b}} \mathrm{e}-17,3^{\mathrm{a}}$. Conclusão: Os dados sugerem que o flúor liberado pelo verniz apresentou maior interação com o esmalte promovendo menor perda mineral quando comparado à solução de diamino de prata. Unitermos: Esmalte dentário; Fluoreto; Verniz; Cárie dentária, prevenção e controle.
} 


\section{INTRODUCTION}

In the present conception, the effect of fluoride on tooth decay control is attributed to its constant presence in the oral cavity, which contributes positively by working directly on the demineralization/remineralization phenomena. Professionally applied topical fluorides are recommended for those individuals who present moderate to severe caries activity, and aims at preventing and/or arresting new or recurrent dental cavities, since supplementary application is able to reduce the carious increment, which is around zero $^{16}$. Professionally applied topical fluorides are used restrictively in dental offices and may be supplied in solutions, gels, varnishes, foams or prophylactic pastes ${ }^{11}$.

The Brazilian assistance programs recommend the use of silver diamine fluoride solutions (cariostatics) ${ }^{24}$ or sodium fluoride varnishes ${ }^{4}$ for children aged 0 to 3 years old at moderate or high activity of tooth decay. Both are suggested as fluoride supplement for preventing enamel caries mainly because of their cariostatic effect, easy application and preventive properties $\mathrm{s}^{4,24,25}$.

The use of these topical products has been supported by several investigations that have evaluated the enamel resistance to acid etching by increasing fluoride incorporation in the enamel or by decreasing the enamel solubility in acids. However, this outcome is not correlated with clinical findings because the effect on caries dynamics has not been studied ${ }^{26}$. Moreover, there are no parameters comparing the use of those two products either concerning enamel resistance to demineralization under conditions that simulated the development of caries or the effect of silver diamine fluoride on sound enamel.

Thus, the aim of this investigation was to study the effect of the application of a fluoridated varnish or a silver diamine fluoride solution on fluoride uptake by sound enamel, and enamel resistance to demineralization in an in vitro cariogenic challenge.

\section{MATERIALAND METHODS}

\section{Experimental design}

Enamel blocks (4X4 mm) were obtained from bovine incisor teeth stored in formaldehyde at $2 \%$, pH 7.0, at room temperature ${ }^{6}$. The blocks were serially polished and flattened for initial surface microhardness (SMH) assessment. Those blocks with microhardness ranging from 326 to $344 \mathrm{KHN}$ (Knoop hardness) units were selected and randomly distributed into 3 groups with 24 specimens each. One group was used as control (C); in the other groups, either a fluoridated varnish (V) or a silver diamine fluoride solution (D) was applied to the enamel. Twelve blocks of each group were submitted to $\mathrm{pH}$-cycling solutions and the others were kept in humid environment until analysis. Half of each block submitted to $\mathrm{pH}$-cycling was designated for surface and cross-sectional microhardness (CSMH) determination, and the other half, as well as those blocks not submitted to $\mathrm{pH}$ cycling, were designated for enamel fluoride concentration analysis.

\section{Treatments and pH-cycling}

A thin layer of fluoridated varnish (Duraphat 2.26\% FpH 7.0, Woelm \& Pharma Co., Eschwege, Germany) was applied with a brush to the enamel blocks of the "V" group. After 24 hours, the varnish was removed carefully with a surgical blade. Removal was completed with cotton swabs soaked in acetone ${ }^{2,19}$. Then, the blocks were washed with deionized water for 1 minute. Silver diamine fluoride (Safluoride di Walter at 30\% - pH 9.0, Polidental, Rio de Janeiro, RJ, Brazil) was applied with a cotton swab to the enamel blocks of the " $D$ " group for 2 minutes. After application, the blocks were washed with a flow of deionized water for approximately $30 \mathrm{sec}$ and lightly dried with absorbent paper. The enamel blocks of groups C, V and D that were not submitted to cariogenic challenge were stored in humid environment until the end of $\mathrm{pH}$-cycling.

Twelve blocks from each group were submitted to a $\mathrm{pH}-$ cycling model simulating a high caries challenge for 7 days, basically according to Vieira et $\mathrm{al}^{23}$. The blocks were kept in demineralizing solution (2.0 mmol L-1 calcium, $2.0 \mathrm{mmol} \mathrm{L}^{-1}$ phosphate in $0.075 \mathrm{~mol} \mathrm{~L}^{-1}$ acetate buffer, $0.02 \mu \mathrm{m} \mathrm{F} / \mathrm{mL}$, pH 4.7) for $3 \mathrm{~h}$ (35.5 mL per block), and in a remineralizing solution (1.5 mmol L $\mathrm{m}^{-1}$ calcium, $0.9 \mathrm{mmol} \mathrm{L}^{-1}$ phosphate, $150 \mathrm{mmol} \mathrm{L}^{-1}$ $\mathrm{KCl}$ in $0.1 \mathrm{~mol} \mathrm{~L}^{-1}$ Tris buffer, $0.03 \mu \mathrm{m} \mathrm{F} / \mathrm{mL}$, pH 7.0) for $21 \mathrm{~h}$ (17.75 mL per block).

\section{Microhardness determination}

After $\mathrm{pH}$-cycling, surface microhardness of the enamel blocks from the $\mathrm{C}, \mathrm{V}$ and $\mathrm{D}$ groups was measured again $\left(\mathrm{SMH}_{1}\right)$. Five indentations spaced $100 \mu \mathrm{m}$ from each other in relation to the baseline were made using the microhardness tester Shimadzu HMV-2000 (Shimadzu Corporation, Kyoto, Japan). The percentage loss of surface microhardness $(\% \mathrm{SML})$ was calculated $\left(\% \mathrm{SML}=\left[\left[\mathrm{SMH}_{1}-\mathrm{SMH}\right] /\right.\right.$ $\mathrm{SMH}] \mathrm{x} 100)^{23}$. Next, the blocks were longitudinally sectioned at the midline. Half of each block was used for crosssectional microhardness (CSMH) determination and the other half for enamel fluoride concentration analysis. For cross-sectional microhardness tests, one of the halves of each block was embedded in acrylic resin so that the sectioned enamel blocks could be exposed and polished. The indentations were made at 20, 40, 60, 80, 100, 200 and $300 \mu \mathrm{m}$ from the outer enamel surface. CMHS values were converted to mineral content (volume \% mineral) using the relation: mineral content $=4.3(\sqrt{ } \mathrm{KHN})+11.3^{7}$. Integrated area (\% min. vol. $\mathrm{x} \mu \mathrm{m}$ ) of sound enamel (Z) and after $\mathrm{pH}$ cycling $\left(Z_{1}\right)$ were calculated ${ }^{1,14,20}$. The percentage change of integrated mineral loss $\left[\% \Delta \mathrm{Z}=\left(\left(\mathrm{Z}_{1}-\mathrm{Z}\right) / \mathrm{Z}\right) \mathrm{x} 100\right]$ was calculated.

\section{Enamel fluoride concentration}

Three thin enamel layers were sequentially removed by immersion of half of each block in $0.5 \mathrm{~mL}$ of $0.5 \mathrm{~mol} \mathrm{~L}^{-1}$ of $\mathrm{HCl}$ for 15, 30 and 60 seconds under constant agitation ${ }^{23}$. An equal volume of TISAB II, pH 5.0 (modified with $20 \mathrm{~g}$ $\mathrm{NaOH} / \mathrm{L}$ ) was added to each solution containing the 
dissolved enamel layer. Fluoride measurements $\left(\mu \mathrm{g} \mathrm{F/ \textrm {cm } ^ { 2 } )}\right.$ were taken using an ion-selective electrode Orion 96-09 and an ion analyzer Orion 720A (Orion Research, Inc., Beverly, MA, USA). The fluoride concentration in each layer was presented as the ratio of fluoride $\left(\mu \mathrm{g} \mathrm{F} / \mathrm{cm}^{2}\right)$ and phosphate $\left(\mu \mathrm{g} \mathrm{P} / \mathrm{cm}^{2}\right)$ values, which was determined by the method of Fiske and Subbarrow ${ }^{8}$.

\section{Statistical analysis}

Data obtained from cross-sectional microhardness $(\% \Delta \mathrm{Z})$ and enamel fluoride concentration measurements (ratio of fluoride and phosphate) were submitted to the analysis of variance and to the Tukey test at 5\% of significance. Heterogeneous variances were detected among the results of the $\mathrm{SMH}, \mathrm{SMH}_{1}$ and \%SML by Shapiro-Wilks normality test. Thus, the Kruskal-Wallis tests - nonparametric multiple comparison tests - were applied to distinguish significant differences among the treatments at the level of $5 \%{ }^{3}$.

\section{RESULTS}

The results obtained for the different groups and treatments with regard to $\mathrm{SMH}, \mathrm{SMH}_{1}$ and $\% \mathrm{SML}$ are shown in Table 1. The values of baseline microhardness (SMH) observed in the control (C), fluoridated varnish (V) and silver diamine fluoride (D) groups were similar ( $p>0.05$ ). The $\mathrm{SMH}_{1}$ and \%SML values of the enamel blocks treated with fluoridated varnish (V) were higher and lower, respectively, than those obtained in the silver diamine fluoride (D) and control $(\mathrm{C})$ groups $(\mathrm{p}<0.05)$. Furthermore, enamel blocks treated with silver diamine fluoride solution presented higher $\mathrm{SMH}_{1}$ and lower \%SML values in relation to the control group $(\mathrm{p}<0.05)$. Concerning mineral loss $(\% \Delta \mathrm{Z})$, the values obtained in the "V" group were significantly lower $(\mathrm{p}<0.05)$ than those in the "D" and " $\mathrm{C}$ " groups, which were similar ( $>0.05)$.

With regard to the F/P ratio at the first and second layers before $\mathrm{pH}$-cycling, all values observed in the different treatment groups were higher than those obtained in the control group (C). The values of F/P ratio observed in the group "V" were higher than those observed in the groups
“C” and "D” before and after $\mathrm{pH}$-cycling, and showed significant difference at the level of 5\%. The distribution of fluoride concentrations throughout the enamel layers and their statistical significance are illustrated in Table 2.

\section{DISCUSSION}

Many in vitro and in vivo studies have been conducted to define the desirable fluoride therapy for dental decay prevention ${ }^{12}$. High frequency application with low concentrations of fluoride agents has been considered the most beneficial treatment regime. However, in situations of high risk of caries, the association of a method that employs high concentration of fluoride such as the professionally applied products has been recommended ${ }^{16}$. In infants, both fluoridated varnish and silver diamine fluoride have been indicated and used due to their easy application and safety on enamel demineralization, even though diamine has been designed to be applied to dentin. However, comparison between these two fluoride agents on enamel demineralization has not been clearly established.

The results of the present study showed that the enamel blocks treated with fluoridated varnish (V) showed better results regarding \%SML, mineral loss $(\Delta \mathrm{Z})$ (Table 1 ) when compared with the control (C) and the silver diamine fluoride (D) groups. The group $\mathrm{D}$, in turn, showed a \%SML value lower than that of the control group (C).

However, mineral loss for group “ $\mathrm{D}$ ” was 2.2 times higher when compared to group " $V$ ". The silver diamine fluoride was not effective to decrease mineral loss $(\% \Delta \mathrm{Z})$ in comparison with the control group. The findings of $\% \Delta \mathrm{Z}$ do not confirm the SMH results regarding the effect of silver diamine fluoride. This difference may be due to the amount and the type of $\mathrm{F}$ compound formed on the surface. The silver diamine fluoride showed a lower $\mathrm{F}$ formed (before $\mathrm{pH}$ cycling) and released (after $\mathrm{pH}$ cycling). Despite the F from silver diamine was able to reduce the \%SML, it was not able to decrease the mineral loss from the subsurface. This may be the reason why fluoride varnish is more efficient to delay lesion progression when compared to silver diamine ${ }^{18}$.

Even though silver diamine provides more soluble fluoride (23.6\%) in comparison with varnish $(15 \%)^{2}$, the results from $\mathrm{F}$ in the enamel showed that higher amounts of

TABLE 1- Analysis of the enamel blocks according to groups/treatments (means $\pm s d ; n=12$ )

Treatments

Analysis

\begin{tabular}{lcccc} 
& SMH & SMH $_{1}$ & $\%$ SML & $\% \Delta Z$ \\
\hline Control & A338.2 $\pm 1.8^{\mathrm{a}}$ & ${ }^{\mathrm{B}} 121.8 \pm 20.1^{\mathrm{a}}$ & $-64.0 \pm 4.9^{\mathrm{a}}$ & $-18.7 \pm 2.7^{\mathrm{a}}$ \\
Varnish & $\mathrm{A} 339.8 \pm 2.5^{\mathrm{a}}$ & ${ }^{\mathrm{B}} 186.2 \pm 16.9^{\mathrm{b}}$ & $-45.2 \pm 4.1^{\mathrm{b}}$ & $-7.7 \pm 3.1^{\mathrm{b}}$ \\
Diamine & $\mathrm{A} 337.2 \pm 3.2^{\mathrm{a}}$ & ${ }^{\mathrm{B}} 158.0 \pm 10.7^{\mathrm{c}}$ & $-53.1 \pm 1.8^{\mathrm{c}}$ & $-17.3 \pm 2.3^{\mathrm{a}}$ \\
\hline
\end{tabular}

Mean values followed by different letters are statistically different at 5\%. Capital letters show difference between SMH and $\mathrm{SMH}_{1}$, and lower case letters among groups. $\mathrm{SMH}$ : initial surface microhardness. $\mathrm{SMH}_{1}$ : surface microhardness after $\mathrm{pH}-$ cycling. \%SML: percentage of surface microhardness loss. \% $\Delta \mathrm{Z}$ : percentage change of integrated mineral loss. 
F are formed and retained in the enamel after treatment with fluoride varnish in all removed layers, except for the third layer of $F$ retained. This fluoride may be released during the cariogenic challenge and may spread into the enamel and reduce the caries lesion progress, propitiating the reprecipitation of less soluble calcium phosphate ${ }^{5}$. This may be confirmed by a higher $\mathrm{F}$ formed / F retained ratio in the "V" group in all enamel layers removed by acid biopsy in comparison with the " $\mathrm{D}$ " and " $\mathrm{C}$ " groups (Table 2). These can be correlated to the $\% \Delta \mathrm{Z}$ : the silver diamine failed to inhibit caries progression.

The amount of $\mathrm{F}$ formed in the enamel depends on the $\mathrm{F}$ concentration and the $\mathrm{pH}$ of the product applied and how long it remains in contact with the enamel. Thus, the better results observed for the group " $V$ " may be related to a longer contact period of the varnish with the enamel and the basic $\mathrm{pH}$ (9.0) presented by silver diamine fluoride.

For the silver diamine group, the F present in enamel did not differ from the control group in many removed layers (Table 2). In the third layer after $\mathrm{pH}$ cycling (F retained), the silver diamine showed lower amount of $\mathrm{F}$ when compared with the control group. This demonstrates that the fluoride released from silver diamine is not able to penetrate in depth in the enamel. Even though fluoride concentration in enamel not always provides conclusive information with regard to the products tested ${ }^{22}$, these observations can be correlated with mineral loss $(\Delta \mathrm{Z})$. The products formed from silver diamine and their interaction with calcium phosphate within the lesion were not effective to decrease caries progression in comparison with the control group.

The worse performance for group $\mathrm{D}$ may be attributed to the formation and dissolution of silver phosphate and silver proteinate and re-precipitation of silver chloride, silver oxide and metallic silver crystals during $\mathrm{pH}$-cycling ${ }^{13}$. Silver may have interfered with the formation of fluoridated deposits and formed silver phosphate, which may compete with fluoride. In contrast, the main product formed after fluoride varnish application is the calcium fluoride, which may act as a fluoride reservoir. During acid challenge, the calcium fluoride dissolves and the $\mathrm{F}$ is released to effectively promote remineralization.

The silver fluoride products are more often used in dentin caries, which present a greater amount of protein substrate, carbonates and phosphates for the reaction. On the other hand, the enamel is short of these substrates in comparison with dentin, which may have decreased the silver diamine fluoride reactivity. This may contribute to the differences observed in the results of the present study ${ }^{10}$. In addition, these results also suggested that it should be convenient to use silver diamine fluoride more frequently than fluoridated varnish to compensate for its lower reactivity. However, this should be evaluated by in situ and further clinical trials.

\section{CONCLUSION}

Based upon the experimental conditions of this study, we concluded that fluoridated varnish was more effective to reduce both the enamel surface demineralization and caries lesion depth than silver diamine fluoride solution.

TABLE 2- Mean ratio of fluoride and phosphate values (F/P $\left.\times 10^{-3}\right)$ before and after $\mathrm{pH}$-cycling in the removed enamel layers (means $\pm \mathrm{SD} ; \mathrm{n}=12$ )

GROUPS Control $\quad$ Varnish $\quad$ Diamine

Before pH-cycling

( $F$ formed)

$$
\begin{aligned}
& 1^{\text {st }} \text { layer } \\
& 2^{\text {nd }} \text { layer } \\
& 3^{\text {rd }} \text { layer }
\end{aligned}
$$

${ }^{A} 1.6 \pm 0.3^{\mathrm{a}}$

B $21.6 \pm 4.0^{\mathrm{a}}$

${ }^{c} 4.0 \pm 0.5^{\mathrm{a}}$

$\mathrm{A} 1.3 \pm 0.3^{\mathrm{a}, \mathrm{b}}$

B $13.2 \pm 2.4^{\mathrm{b}}$

${ }^{\mathrm{c}} 2.4 \pm 0.5^{\mathrm{b}}$

After pH-cycling

( $F$ retained)

$$
1^{\text {st }} \text { layer }
$$$$
{ }^{\mathrm{A}} 0.9 \pm 0.2^{\mathrm{b}, \mathrm{c}}
$$

\begin{tabular}{|c|c|c|c|c|}
\hline \multirow[t]{3}{*}{$\mathrm{F}$ retained } & $1^{\text {st }}$ layer & 0,8 & 6,3 & 2,3 \\
\hline & $2^{\text {nd }}$ layer & 0,9 & 8,8 & 2,6 \\
\hline & $3^{\text {rd }}$ layer & 1,5 & 10,6 & 3,0 \\
\hline
\end{tabular}

B $7.4 \pm 1.5^{\mathrm{c}}$

${ }^{\mathrm{A}} 1.2 \pm 0.3^{\mathrm{c}, \mathrm{e}}$

Ratio F formed /

Mean values followed by different letters are statistically different at $5 \%$. Capital letters show differences between the treatment groups; lower case letters show differences between the enamel layers removed within the same group. 


\section{REFERENCES}

1- Arends J, Ten Bosch JJ. Demineralization and remineralization evaluation techniques. J Dent Res. 1992;71(sp. Issue):924-8.

2- Bruun C, Givskov H. Formation of $\mathrm{CaF}_{2}$ on sound enamel and in caries-like enamel lesions after different forms of fluoride applications in vitro. Caries Res. 1991;25:96-100.

3- Campos GM. GMC 2002 [computer program]. Ribeirão Preto: School of Dentistry, http://www.forp.usp.br/restauradora/gmc/ gmc.html\#gmc. Accessed on Feb 21, 2003.

4- Cunha RF, Delbem ACB, Percinoto C, Saito TE. Dentistry for babies: a preventive protocol. J Dent Child. 2000;67:89-92.

5- Delbem ACB, Cury JA. Effect of application time of APF and NaF gels on microhardness and fluoride uptake of in vitro enamel caries. Am J Dent. 2002;15:169-72.

6- Delbem ACB, Cury JA, Nakassima CK, Gouveia VG, Theodoro LH. Effect of Er:YAG laser on $\mathrm{CaF}_{2}$ formation and its anti-cariogenic action on human enamel - an in vitro study. J Clin Laser Med Surg. 2003;21:197-201.

7- Featherstone JDB, ten Cate JM, Shariati M, Arends J. Comparison of artificial caries-like lesions by Quantitative microradiography and microhardness profiles. Caries Res. 1983;17:385-91.

8- Fiske CH, Subarrow Y. The colorimetric determination of phosphorus. J Biol Chem. 1925;66:375-400.

9- Gantt DG, Silverstone LM, Hicks MJ. Prism and cristal structure of human and bovine enamel. Caries Res. 1985;19:184-5.

10- Gotjamanos T. Pulp response in primary teeth with deep residual caries treated with silver fluoride and glass ionomer cement (“Atraumatic" technique). Aust Dent J. 1996;41:328-44.

11- Lecompte EJ. Clinical application of topical fluorides productsrisks, benefits, and recommendations. J Dent Res. 1987;66:106671.

12- Marinelli CB, Donly KJ, Wefel JS, et al. An in vitro comparison of three fluoride regimens on enamel remineralization. Caries Res. 1997;31:418-22.

13- Moriwaki Y, Shimizu A, Nonomura E, Sobue S, Tsutsumi S. X-ray microbeam diffraction studies on the effect of diammine silver fluoride. J Jap Soc Dent Appar Mater. 1974;15:142-8.

14- Ögaard B, Rölla G, Arends J. In vivo progress of enamel and root surface lesions under plaque as a function of time. Caries Res. $1988 ; 22: 302-5$

15- Ögaard B. $\mathrm{CaF}_{2}$ formation: cariostatic properties and factors of enhancing the effect. Caries Res. 2001;35:40-4.

16- Ögaard B, Seppä L, Rölla G. Professional topical fluoride applications. Clinical efficacy and mechanism of action. Adv Dent Res. 1994;8:190-201.

17- Okamoto M, Nonomura E, Sobue S. Scanning electron microscopics studies on intact enamel surface after topical application of diammine silver fluoride. Jap J Pedodont. 1975;13:78-84.

18- Petersson LG, Derand T. Development of artificial carious lesions in enamel after F-varnish (Duraphat) and F-Fe-Al-solution treatment. Swed Dent J. 1981;5:219-23.

19- Sorvari R, Meurman JH, Alakuijala P, Frank RM. Effect of fluoride varnish and solution on enamel erosion in vitro. Caries Res. 1994;28:227-32.
20- Sullivan RJ, Fletcher R, Bachiman R, Penugonda B, LeGeros RZ. Intra-oral comparison and evaluation of the ability of fluoride dentifrices to promote the mineralization of caries-like lesions in dentin and enamel. J Clin Dent. 1995;6:135-8.

21- Suzuki T, Nishida M, Sobue S, Moriwaki Y. Effects of diammine silver fluoride on tooth enamel. J Osaka Univ Dent Sch. 1974;14:6172

22- Ten Cate JM, Mundorff-Shrestha SA. Working group report 1: laboratory models for caries (in vitro and animal models). Adv Dent Res. 1995; 9(3):332-4.

23 - Vieira AEM, Delbem ACB, Sassaki, KT, Rodrigues E, Cury J, Cunha RF. Fluoride dose-response in $\mathrm{pH}$ cycling models using bovine enamel. Caries Res. In press 2005.

24- Walter LRF, Nakama L. Prevention of dental caries in the first year of life. J Dent Res. 1994;73:773.

25- Weinstein P, Domoto P, Koday M, Leroux B. Results of a promising open trial to prevent baby bottle tooth decay: a fluoride varnish study. J Dent Child. 1994;61:338-41.

26- Zero DT. In situ caries models. Adv Dent Res. 1995;9:214-30. 